\title{
Pauliina Haasjoki
}

\section{Ambivalenssin "arvoituksellinen sulo": Hagar Olssonin Silkkimaalaus}

Tämä satu on sellainen ettei sitä voi unohtaa, siihen kätkeytyy salaisuus. Seisoin hetken hiljaa ja tutkin sitä sydämessäni ja iloitsin sen arvoituksellisesta sulosta. (S 20.)

Näin sanoo Hagar Olssonin Silkkimaalauksen (= S, Kinesisk utflykt, 1949; suom. Eeva-Liisa Manner, 1954) päähenkilö Hagar kiinalaisesta Tsh’ienniangin legendasta. Hagar näkee itsensä nukkumassa lapsuutensa huoneessa ja saa kuulla nukkujan olevan Tsh'ienniang, nuori nainen, joka karkasi vanhempiensa kodista rakastamansa miehen kanssa. Ristiriita vanhempien tahdon ja oman rakkauden välillä kahdensi Tsh'ienniangin niin, että yksi Tsh'ienniang makasi tiedottomana isän talossa ne vuodet, jotka toinen eli Vang Tshoun kanssa vaimona ja äitinä. Ihme paljastuu, kun Tsh'ienniang matkustaa vanhempiensa luokse etsimään sovintoa. Edeltä mennyt Vang Tshou saa kuulla Tsh'ienniangin maanneen koko ajan vuoteessaan. Nukkuja herää ja kulkee toista Tsh'ienniangia vastaan, ja nämä kaksi yhdistyvät kaikkien onneksi.

Hagar tulee solmituksi Tsh'ienniangiin, ja samastuminen jatkuu läpi teoksen. Hagar tuntee joutuneensa syrjään elämästään ja rakkaimpiensa syyttämäksi, mutta saa itsensä ja rauhansa takaisin fantasiassa tekemällään matkalla. Tsh'ienniangin legenda kokoaa yhteen Silkkimaalauksen tärkeimpiä teemoja: ristiriidan, sovinnonkaipuun, erkanemisen itsestä, rakkauden vastaanottamisen tai hylkäämisen valinnan, mysteerin. Legenda tekee teoksesta allegorisen ja ohjaa lukemaan kohtauksia variaatioina keskeisestä asetelmasta. Mutta paljastuuko legendaan "kätketty salaisuus" vai jääkö kahtiajakautumisen merkitys salaisuudeksi? Silkkimaalaus on arvoituksellinen teos. Sen kerronta on yhtä aikaa arkaaisen perinteistä ja hienovaraisen kokeilevaa. Se osattiin aikanaan kytkeä Olssonin elämään ja etenkin pitkäaikaiseen naisystävään Ella Frelanderiin, johon omistus "Kàn muistolle" viittaa. Teoksen mysteeriluonne ja sen heteroseksuaalisen oletusarvon ylittävä rakkauden ja sukupuolen kertominen herättävät toisiinsa punoutuvia kysymyksiä. Jos kaksijakoisuus viittaa usein ainakin verhotusti sukupuolen kaksijakoisuuteen ja jos salaisuus on erityisellä tavalla seksuaalisuutta koskeva salaisuus, onko myös Tsh'ienniangin legendaa luettava juuri seksuaalisen tiedon ja kahtiajaon kuvana?'

Näiden kysymysten pohtiminen vie queer-lukemiseen. Ymmärrän queer-teorian 
merkitsevän kriittistä mielenkiintoa, joka kohdistuu sukupuolen ja seksuaalisuuden poissulkevaan kaksijakoisuuteen ideologioina ja ajattelun rakenteina. Queer-sana sisältää pervessin, homoseksuaalisen, oudon ja askarruttavan merkitykset. Merkityskirjoa hyödyntävä queertutkimus kysyy, mitä sukupuolesta ja seksuaalisuudesta oletetaan tiedetyksi ja miten (hetero)seksuaalisuutta luonnollistetaan osana sukupuolijärjestystä. Se on myös toisenlaista tietoa tuottavaa kriittisyyttä. (Ks. Rossi 2003, 121; Kekki 2004, 34-35; Karkulehto 2007, 28-29.) Queer-lukeminen taas tuo mukaan kerronnallisuuden ja kirjallisten muotojen erityisyyden, ja näin se voi tarkastella seksuaalisuuden ja narratiivisuuden toisiinsa vaikuttavia rakenteita. Kertomuksia tarkasteleva queer-tutkimus on suhtautunut epäilevästi narratiivisuuteen, sillä sen on tyypillisessä ajallisen ja loogisen peräkkäisyyden muodossaan nähty solmiutuvan heteroseksuaalisuutta luonnollisena säilyttävään järjestykseen (Jagose 2002; Roof 1996).

Myös kerronnan queer-tutkimuksessa on usein, vaikka ei suinkaan aina (esim. Karkulehto 2007; Rosenberg 2004), jäänyt vähemmälle huomiolle homoseksuaalisuuden ja heteroseksuaalisuuden väliin jäävä tila. Oma tutkimukseni on käsitellyt biseksuaalisuuden kerronnallista hankaluutta oireena siitä, millainen yhteys sukupuolen ja seksuaalisuuden kaksijakoisuudella on kertomisen käytäntöihin ja miten myös kerronnassa vaikuttaa eräänlainen ambivalenssia hylkivä kaksijakoisuus. (Ks. esim. Haasjoki 2005, 2007.) Toisaalta kirjalliset traditiot ovat täynnä kerronnallisia keinoja, jotka toimivat tätä hallitsevaa dynamiikkaa vastaan, ja monimerkityksisyys ja hälyvyys kerronnassa näyttävät usein luovan hedelmällisen tilan feministiselle ja queerlukemiselle (ks. esim Mezei 1996).

Sekä kerronnassa että sukupuolessa ja seksuaalisuudessa on kysymys tiedosta ja kaksijakoisuudesta: kumpi; saivatko he toisensa; mikä lopulta oli totuus, mikä valhe. Kun tieto ei ole selkeää tai pysyvää tai kun ollaan vasta matkalla kohti tietoa, vallitsee häilyvyys ja kahtalaisuus, ambivalenssi. Ambivalenssi on poissulkevan kaksijakoisuuden väistämätön seuralainen, ylijäämä, jonka poissulkemisessa kahtiajako toteutuu. Homoseksuaalisuuden ja heteroseksuaalisuuden vastakkaisuudelle perustuvassa ihmiskuvassa ambivalenssi on toisaalta biseksuaalisuutta, toisaalta aina vielä nimettömämpää, häilyvämpää tietoa. Ambivalenssilla on tyypillisessä tarinassa ja myös arkkityyppisessä seksuaalisen identiteetin tarinassa tärkeä osa: varmuus rakennetaan epävarmuudesta kertomalla ja järjestelemällä. (Ks. Haasjoki 2005, 31-32; Haasjoki 2007, 160-162.) Se, miten ambivalenssi ilmenee ja mitä sille tarinan logiikassa tapahtuu, on kiinnostava queer-lukemisen kysymys.

Silkkimaalauksessa tehdään tiliä kuolleiden rakkaiden kanssa. Henkilönnimien käyttö ja Olssonin omat lausunnot teoksesta sallivat olettaa, että syyttäviltä tuntuvat rakkaat ovat Olssonin elämän tärkeitä henkilöitä: isä ja äiti, nuoruuden sulhasmies 
R. R. Englund, Edith Södergran ja 1930-luvun elämänkumppani Ella Frelander eli Ka (Holmström 1995, 102). Olssonin eroottiset ja romanttiset suhteet ovat kiinnostaneet hänen teoksistaan kirjoittaneita. ${ }^{2}$ Elämäkerrasta voisi muodostaa kuvan naisesta, joka ei purkautuneen kihlauksensa jälkeen koskaan mennyt naimisiin, tai toisaalta naisesta, jolla oli suhteita naisiin tai jolla oli suhteita sekä naisiin että miehiin. Erilaiset kuvat Olssonista heijastunevat myös teoksen henkilöasetelmiin eri tavoin painottuviksi tulkinnoiksi.

Päivi Karttunen lukee teoksen keskeiseksi teemaksi purkautuneen (heteroseksuaalisen) kihlauksen, joka merkitsee selän kääntämistä rakkaudelle (Karttunen 1989, 367). Mari Koli puolestaan tulkitsee teoksen verhotuksi tunnustukseksi naisten välisestä rakkaudesta ja juuri siinä koetun ristiriidan sovitukseksi (Koli 1996). Silkkimaalaus kaunokirjallisena teoksena sallii mielestäni molemmat luennat. Erotellessaan nämä temaattiset linjat lukija on kuitenkin jo astunut kaksijakoisen puheen piiriin, mitä tulee rakkauteen ja sen sukupuoliin, ja myös määrätietoisesti ne molemmat sisällyttävä luenta osallistuu samaan kaksijakoisuuteen. Seksuaalisuuden normaalius tai epänormaalius on Silkkimaalauksen tyylille vieras käsitteellistys. Ystävä- ja rakastettusanat tuntuvat kantavan tarkoituksellisen ajatonta ja sukupuoleltaan määräämätöntä merkitystä. Rakastetuksi kutsutulla on toisaalta Ka’n kasvot, toisaalta samalle paikalle voivat asettua muutkin tarinan merkitykselliset ihmiset, muistellut ja kuvitellut, niin että rakastettu-sanalla on myös "toisen ihmisen" merkityssisältö. Silti teos on aistillinen ja eroottinen. Se nimeää "värisevät kutsut" ja kosketuksesta leimahtavan halun.

2000-luvun lukija, joka on tottunut ajattelemaan sukupuolta ja seksuaalisuutta poissulkevan kaksijakoisuuden järjestelmänä ja lukemaan kertomuksia pitäen silmällä, mahdollistavatko vai kieltävätkö ne muun kuin heteroseksuaalisen tarinan, olisi ehkä valmis näkemään Tsh'ienniagin legendan allegoriana homo- ja heteroseksuaalisuuden ylittävästä harmonisesta kahtalaisuudesta. Onko legenda siis rakenteellinen elementti, joka kantaa seksuaalisen ambivalenssin teemaa? Onko siinä esiintyvä parantava yhteenliittyminen metafora biseksuaalisuudelle, joka muodostuu eri- ja samansukupuolisista rakkauksista, kun ne itsetuntemuksessa kerrotaan samaan kertomukseen? Vai onko legendan erkanemisella ja yhtymisellä toisenlainen merkitys, ja millainen silloin on Silkkimaalauksen tarina eri- ja samansukupuolisesta rakkaudesta?

\section{Kuvissa ja ajassa liikkuva kerronta}

Ajattelen Silkkimaalausta teoksena, jossa rakenteen ja tematiikan ambivalenssi kulkevat yhdessä. Hagar Olssonin tuotannossa kohtaavat kerronnalliset ja yhteiskunnalliseettiset uudistuspyrkimykset - modernismi, naiseuden uudelleenajattelu ja sotienjälkeinen henkinen jälleenrakennustyö. ${ }^{3}$ Myös Silkkimaalaus liittää yhteen kokeilevat kerrontarakenteet, sukupuolen ja seksuaalisuuden teemat ja historiallisen het- 
kensä ajattelun haasteet. Olsson etsi Jag lever -esseeteoksessaan (1948) kuumeisesti vaihtoehtoa rationaalisuudelle ja kokonaisuutensa kadottaneelle ihmiskuvalle. Myös Silkkimaalauksen mysteeriä tavoitteleva runollisuus asettuu ambivalenssina vasten tätä liiallista selkeyttä. Lisäksi ambivalenssin käsite valaisee teoksen rakennetta. Läheltä lukemalla voi nähdä, miten kerronnallinen ambivalenssi syntyy tilallisten ja ajallisten rakenteiden yhteisvaikutuksena.

Alkukielinen Silkkimaalaus on sadan pienen ja kevyesti ladotun sivun kirja. Se ei ole mitoiltaan edes pienoisromaani, muttei myöskään laaja novelli. Sitä on parasta kutsua kertomukseksi. Siinä on ajallisen juonen taso, joka kuitenkin on eräänlainen kehystys. Tämä taso koostuu Hagarin tekemästä matkasta, joka alkaa hänen huoneestaan ja päättyy sinne. Silkkimaalauksen kehyskertomuksen juoni on monin tavoin odotuksenmukainen. Se on matkajuoni, ja sen voi nähdä Peter Brooksin kuvaamana metaforisena kokonaisuutena: alku ja loppu ovat "sama mutta eri", ne samastuvat mutta niiden välille jännittyy merkityksen muutos ja siirtymä. (Books 1984, 91-92.) Juonen sisältö on kysymysten asettaminen ja vastausten saaminen matkalla, joka on samalla metaforinen matka itseen ja menneisyyteen.

Tämä narratiivinen norminmukaisuus kuvaa siis kehyskertomusta. Suurin osa kerronnasta on sijoitettu siihen joko mietteliäänä monologina tai upotettuina kertomuksina ja kuvallisina laajennuksina. Näin rakentuu muutamia keskeisiä tapahtumisen näyttämöitä, joiden välillä liikutaan. Paikkojen järjestys ja niiden suhteet muodostavat Silkkimaalauksen varsinaisen juonen: alun ja lopun yksinäisen huoneen välillä sijaitsevat tärkeimpinä Tsh'ienninangin talo, mandariinin talo, puutarha ja paviljonki. Hagar tekee siis matkan Tsh'ienninangin Kiinaan ja arvoituksellisen mandariinin luokse, sekä samalla oman menneisyytensä paikkoihin. Kertomus hahmottuu kerroksittaisena fantasian ekfrasiksena. Käytän ekfrasis-termiä korostamaan näkymien ja näkyjen keskeisyyttä kerronnan kuljettajina. Hyvin usein uuden jakson tarinassa aloittaa kuvaus, joka muistuttaa maalauksen kuvailua:

Näin edessäni kaislikkoisella virran rannalla pienen talon missä Vang Tshou ja Tsh'ienniang asuivat onnellisen maanpakonsa ajan, ja kun vuorten väri vaihtui ruusunpunaisesta purppuraan ja muutama villihanhi lehahti kaislikosta kirkuen lentoon, näin pitkän hahmon nousevan ylös pengermää ja menevän taloon. Oliko hän saattajani? Minä en sitä tiedä, sillä miten etsinkin kaikki nurkat ja sopet ja kurkistin jokaisen verhon taa, en voinut nähdä häntä missään. (S 20.)

Kertoja siirtyy tilasta toiseen, näkymän katselijasta talossa olijaksi, "muinaiseen Kiinaan". Vaikka näkymässä on liikettä, sitä kuvaillaan harmonisena sommitelmana ja sen estetiikka on kiinalaisen maalauksen estetiikkaa. Yksityiskohtien kuvailu (talo, sopet, nurkat ja verhot) mahdollistaa astumisen sisään kuvaan; yksityiskohtaan tarkentaminen tekee kuvatusta kosketeltavan, ja siirtymä kerronnan tasojen välillä on mahdollinen. Kerronnan siirtymiä voi siis kuvata ekfrasiksen lisäksi synekdokeen 
käsitteellä, joka on metonymian sukulaistrooppi ja merkitsee siirtymää kokonaisuuden ja osan välillä. ${ }^{4}$ Merkittävää näissä kerronnan troopeissa on niiden visuaalinen tilallisuus, joka asettuu vasten matkajuonen ja elämäntarinan kertomisen ajallista järjestymistä. Ne ovat kuin huoneita talossa, tauluja huoneen seinillä, käytävien labyrintteja tai toistensa sisältä aukeavia laatikoita.

Kertomuksen paikkojen välillä vallitsee enteiden, heijastumisten ja vastaavuuksien verkosto. Alun "tyhjällä näyttämöllä” on näkyvissä esineitä, jotka myöhemmin saavat ratkaisevia merkityksiä, kuten sormus ja maalaus, jolla on Ka’n profiili. Lause "Ujo nuorukainen kuiskasi korvaani muutaman sanan" täydentyy myöhemmin kertomukseksi nuoruuden kihlatusta (S 13-14). Vaikka jotkin kerronnalliset siirtymät ovat yllättävämpiä kuin toiset, kaikki ovat motivoituja. Siirtymät noudattavat ekfrasisrakennetta tai seuraavat kellon soittoa, enteilevää runonsäettä tai edellä kulkevaa saattajahahmoa. Saattaja muodostaa spektrin selittämättömästi tutusta, kaukaa nähdystä hahmosta mandariiniksi, joka lopulta tunnistetaan isäksi. Saattajan aavistettava läsnäolo, vihjeet ja enteet ovat kuin sadun juonenkuljetusta, joka asettaa sankarin suoriutumaan tehtävästä. Kertomus ei jakaudu unen ja valveen tasoksi vaan synnyttää omanlaisensa todellisuuden. Silkkimaalaus on tarkka sommitelma niin tyyliltään kuin rakenteeltaan, mutta vaikka se ei ole rönsyilevä ja satunnainen, siinä on kuitenkin aika- ja tilarakenteiden muodostamaa mosaiikkimaista monimutkaisuutta ja kolmiulotteisuutta.

Ajan ja tilan välillä vallitsee narratiivisuudessa epäsymmetria, jolla on vaikutuksia niin rakenteen, teemojen kuin ideologisuudenkin tasolla. Ajan kuluminen ja ajassa jäsentyminen esitetään usein tunnisteiksi narratiiville. Kerronnallinen minimi voidaan kuvata siirtymänä kahden ajallisen pisteen välillä, joiden suhde on jännitteinen. Jotakin siirtyy, ratkeaa tai täyttyy samalla kun alku ja loppu solmitaan yhteen, ja kaikki niiden välillä on ajassa tapahtuvaa matkan tekemistä. (Brooks 1984, 21-27; Roof 1996, 51-56.) Ajan keskeisyys on normatiivista, sillä kronologiset liikkeet näyttävät yhdensuuntaisilta, kertakaikkisilta ja jotenkin tarpeellisilta. Kronologia luonnollistaa kausaalisuutta ja hierarkkista järjestystä: ensin tämä, sitten tuo; koska tämä, siksi tai siitä johdettuna tuo. (Ks. Jagose 2002, ix.) Jännite ja sen purkautuminen merkitsee myös tietoa, jota alussa ei ole ja joka lopussa saavutetaan. Tieto ja hallinta tuntuisivat loppuun mennessä siivoavan kertomuksesta ambivalenssin, jolle jäisi paikka vain tarinan keskikohdassa. Keskikohdan hajaannuksen selvittäminen vahvistaa jo alusta alkaen toivotun lopun järjestyksen. (Roof 1996, xix-xxi, 73-75.)

Tilallisten rakenteiden korostumista ajallisten kustannuksella taas on pidetty kerronnan kokeellisuuden merkkinä. Modernin ja postmodernin itsetietoisen romaanin teoreetikot ovat puhuneet tilallistuvasta muodosta, jossa kerronnan virtaava eteneminen ja merkityksen muodostaminen monimutkaistuvat (Waugh 
1984, 23; Frank 1963). Ajallisuus nähdään tässä keskustelussa niin vahvasti kertovaa proosaa dominoivana, että tilallisen muoto syntyy jo pelkästä kronologisuuden häivyttämisestä. Kerronnan tilallisuuden keinoina on pidetty myös visuaalista hahmottumista sekä kehys- ja upotusrakenteita. (Ks. Smitten \& Daghistany 1981.) Esimerkiksi mise en abymejen, koko tarinalle allegoristen sisätarinoiden, jollainen Tsh'ienniangin legendakin on, voi nähdä muodostavan ajallisuuteen tunkeutuvaa tilallisuutta (Rojola 1995, 52).

Analogiset ja toisiaan peilaavat kertomukset luovat toistoa, paluuta ja sisäkkäisyyttä, jossa sekä kertomisen että lukemisen teot alkavat hahmottua tilassa. Tilallisuus mahdollistaa kokemuksen liikkumisesta muullakin kuin aika-akselilla ja samalla kausaalisuuksia vastaan, mahdollisesta kehkeytymisen linjasta toiseen. Sodanjälkeisessä suomalaiskirjallisuudessa näkyy kerronnallisen kokeilun juonne, jossa sivullisuuden teemaan yhdistyy pelkistetty, suljettu tila, niin että tilallisuuden korostus sekä vieraannuttaa että tutkii vierautta temaattisesti (Hökkä 1999, 71). Silkkimaalauksenkin alkua hallitsee tällainen tilallisuutta etualalle tuova tyhjä näyttämö.

Tilallisuus siis vaatii, pysäyttää, ylläpitää ja haastaa, kun taas ajallisuus siivittää, vauhdittaa, täyttää odotukset, purkaa ja päättää. Tilallisuuteen kytkeytyy ristiriidan säilyttäminen, ristiriitaisen kokonaisuuden hallinta, kronologisuuteen taas ristiriidan ratkaiseminen ja kokonaisuuden hallinta lopullisessa tiedossa. Tiedon ja narratiivin yhteydessä voi lisäksi nähdä metaforista sukupuolisuutta ja seksuaalisuutta. Jännitteen, pitkittämisen ja täyttymisen metaforat ovat helposti erotisoituvia, ja monien narratologien tavassa puhua narratiivisesta jännitteestä liikettä synnyttävänä ”vastakohtien vetovoimana" voi nähdä molemminpuolisen luonnollistavan suhteen heteroseksuaalisten instituutioiden ja kerronnallisuuden välillä. (Roof 1996, 49-56.)

Aika- ja tilarakenteisiin liittyy normatiivisuuden ja epänormatiivisuuden ${ }^{5}$ asetelma, jolla on sukupuolittunut sävy. Tällöin se tapa, jolla Silkkimaalaus monimutkaistaa ajallista juontaan tilallisilla siirtymillä, on mielenkiintoinen myös muun kuin teoksen rakenteen kannalta.

\section{Sulkeutumaton minän tarina}

Paljon kommentoidussa Peter Brooksin Reading for the plot-teoksessa (1984) kerronnasta puhutaan jännitteenä, joka haluaa täyttymistään mutta ei aivan vielä. Jotta tarina sisältäisi muutakin kuin alun ja lopun, joita mikään ei lopulta erottaisi toisistaan, tarvitaan kyllin pitkä viivytys, varmuuden ja täyttymisen lykkäys (Brooks 1984, 3538, 48). Mallintaessaan narratiivia Brooks käyttää freudilaista yksilönkehityksen ja seksuaalisuuden tarinaa arkkinarratiivina. Seksuaalisuutta säätelevät narratiivit ovat riippuvaisia ambivalenssista kuviteltuna moninaisuutena, josta luonnollistettu kaksinapainen, heteroseksuaalinen systeemi voidaan johtaa (ks. esim. Garber 2000, 
181-184). Kaunokirjalliset teokset taas voi nähdä riippuvaisina jännitteestä hajanaisuuden ja koherenssin, tiedon ja ei-tiedon välillä, ja tätä jännitettä on kuvailtu metaforisesti "haluna", sukupuolittuneena ja seksuaalisena (Brooks 1984, 104-105). Tällä narratiivin ja seksuaalisuuden yhteenkietoutumisella on väistämättä merkitystä myös sille, millaisia kirjalliset kertomukset rakkaudesta ja halusta ovat tai voivat olla.

Sen tiedollisen järjestyksen mukaisesti, jota Sedgwickin kaapin epistemologia kuvaa, epätietoisuuden oletetaan viittaavan ensinnäkin aidompaan, piilotettuun tietoon ja toiseksikin homoseksuaalisuuteen, joka erotetaan jyrkästi heteroseksuaalisuudesta (Sedgwick 1990). Häilyvyys saa siis harvoin ilmaisua itsenään, vaan se tulkitaan viittaukseksi aivan tietynlaiseen tietoon, joka pitää paljastaa. Ambivalenssin yli on kuljettava kohti lopun hallintaa, se on ratkaistava; seksuaalisuuden tietämisen tilat ("kaapin" sisä- ja ulkopuoli) erotetaan toisistaan, ja niiden välillä on vain yhdensuuntainen ja kertakaikkinen liike. Kehitystarina ja ulostulotarina, joita kerronnan traditioina kannattelee itseä koskevan totuuden etsiminen, näyttävät miten kronologinen juoni tuottaa varmuutta ja kertakaikkisuutta, joka voi olla normatiivista (Roof 1996, 105-107; Haasjoki 2005, 31).

Silkkimaalaus on itseksi tulemistaan kaipaavan minän tarina. Kerrontaa hallitseva päämäärä on näyttää menneisyys ja sen mahdollisuudet, sekä toteutuneet että toteutumattomat, jotta Hagar voisi ymmärtää menetyksen ja syyllisyyden tunteensa ja saada rauhan. Tiedon saaminen muodostuu enteestä ja sen toteen käymisestä, kaukaa nähdystä kuvasta ja sen näkemisestä lähempää. Lähempää katsominen tuottaa tunnistamisen, ymmärtämisen ja usein sovun. Kuvina ja tiloina hahmottuva kerronta ei pyri syrjäyttämään ajan keskeisyyttä, minän historian ja etsimisen tarinallisuutta. Kokemuksellinen ja muisteltu aika on edelleen tärkeä yhdistävä punos. Tilallisuus kuitenkin antaa mahdollisuuden ambivalenssille, joka harvoin selviää juonen kausaalisuudesta.

Eräässä kohtauksessa Hagar tuo toisesta ajasta oman nuoremman itsensä oppaaksi matkalle. Kerronta on siirtynyt hetkeksi lapsuuden makuuhuoneeseen ja Hagar on saanut puhua kadottamansa äidin kanssa. Äiti tunnistaa Hagarin pikku tyttärekseen, mutta suhde on niin ristiriitaisesti kaipuun ja odotusten sävyttämä, että aikuinen Hagar jää lopulta huutamaan äitiään. Tässä kohdassa lapsi-Hagar tarttuu käteen ja ruumiillistuu muistoista suojelevaksi hahmoksi. Lapsi-itsensä kanssa Hagar kykenee astumaan aikaisemmin lukittuun mandariinin palatsin kabinettiin, johon hänet on ohjattu. Kabinetissa Hagar näkee seinillä elämänsä tapahtumia, upotettujen tarinoiden konkretisoituneita ekfrasiksia. Eräs niistä näyttää nuoruuden odottavan tunnelman, sitä jakamaan saapuvan nuoren miehen, kihlatun, ja kihlauksen purkautumisen:

Mutta miksi hänen [nuoren Hagarin] kasvonsa yhtäkkiä tummuivat, miksi hän kääntyi pois ja karisti kukat hiuksistaan, aivan kuin päästäkseen eroon nii- 
den kertomasta sadusta? En tiennyt mihin ryhtyä häntä hillitäkseni - eikö hän käsittänyt, että hän ryösti minulta parhaimman osan korvaamatonta elämääni, suloisen kukinnan, varhaiskevään tuoksun? [- - Minä en tuntenut mitään sääliä häntä kohtaan, päinvastoin sydäntäni vihloi katkera viha. [- - ] Hänen tähtensä olivat huuleni kuihtuneet kuin janoiset kukat, ja sylini oli tyhjä.” (S 43-44.)

Lapsi-Hagar asettuu sovinnontekijäksi keski-ikäisen ja nuoren Hagarin välille ja ohjaa kertojaa ymmärtämään, ettei tyttö yksinkertaisesti "osaa leikkiä toisten kanssa” (S 45).

Kun Hagar monistuu kolmeksi eri-ikäiseksi itsekseen, menneisyyden kohtaaminen saa kirjaimellisen muodon. Kertomuksessa on kysymys muistoista ja eletyn elämän ymmärtämisestä, jota kannattelee ajallinen jatkuvuus. Silti jatkuvuus rikkoutuu, kun menneisyys asettuu nykyisyyden rinnalle samaan tilaan, kohdattavaksi. Kehitystarinan logiikan mukainen maailmaan lähteminen on jo menneisyydessä, ja nyt tehtävä matka on aikaa ja kausaalisuutta vastaan käyvä, uudelleenymmärrystä etsivä. Lapsi-Hagarin ymmärtäväisyys ja tyttö-Hagarista käyty neuvottelu näyttävät, miten menneisyys ei ole suljettu eikä itseymmärrys ainoastaan kronologisuuden ja loogisuuden varassa. Purkautunut nuoruuden kihlaus on tehnyt Hagarista "rakkaudettoman", ikään kuin teoksen läpi etsittävää rakastettua, Ka’ta, ei olisi koskaan ollutkaan. Tiloiksi ja kuviksi fragmentoituva elämäntarina sallii tämän kohtauksen (Hagarin näyn ja hänen vihanpurkauksensa) olla totta siinä missä muidenkin.

Silkkimaalauksen kertoma minän tarina on siis toisenlainen paljolti tilallisuuden vuoksi. Mandariinin palatsin tilojen ja aikojen sisäkkäisyys sallii myös kertoa Ka’sta ja Hagarista sekä istumassa rakastavaisina sohvalla että samassa huoneessa auttamattomasti eri todellisuuksiin kuuluvina (S 33,37). Samoin käy, kun Hagar pysähtyy ihailemaan puutarhan virtaavaa vettä, ja näkee sen lähteellä Edith Södergranin kapeaharteisen hahmon: tämä on virran Hagariin yhdistämä mutta ajan ja syyllisyyden hänestä erottama (S 32). Palatsissa harhaillessaan kertoja saa useita, ajassa rinnakkaisia kokemuksia, ja niissä hän näyttäytyy itselleen monina hahmoina ja etsii sopua näiden välille. Tilallisten ja ajallisten siirtymien yhteisvaikutus tuntuu pyrkivän kohti inhimillistä kokemusta, jossa itsellä on tarina ja logiikka mutta se ei ole jokaisesta paikasta ja joka hetkenä tarkasteltuna sama.

\section{Legenda kahtiajakautuvasta naisesta}

Siirtymät ajassa ja todellisuuksissa ovat taikatemppuja kertojan samuudella. Hagar muuttuu aina hieman toiseksi, mutta hänen kokemuksellinen yhtenäisyytensä pysyy ja kertojanääni saumaa katkokset. Astuessaan Tsh'ienniangin taloon kertoja alkaa kertoa Tsh'ienninangin ruumiillisesta kokemuksesta, joka on toista kuin mihin hän on tottunut: "Hengitin aivan toisin kuin ennen, paljon syvempään kuin koskaan olen voinut hengittää - - " (S 21). Kertoja jättää sanomatta "tunsin olevani Tsh'ienniang”. Sen sijaan 
sana 'minä saa heti siirtymän tapahduttua kaksi merkitystä, Tsh'ienniangin ja Hagarin minuuden. Kertoja monistuu. Katsoessaan itseään peilistä hän katsoo samanaikaisesti itseään ja jotakuta toista: "Mutta olinko minä todella tuo nainen? Sysimustaa tukkaa, pehmeitä valkeita olkapäitä, koko tuota haurasta olentoa ympäröi sädehtivä kauneus, joka tuntui minusta vieraalta, ylimaalliselta.” (S 30.) Peiliin katsovat päällekkäin Hagar, joka arvelee olevansa Tsh'ienniang, ja Tsh'ienniang, joka ihmettelee omaa kauneuttaan ja näyttää omissa silmissään maanpaossa eläneeltä prinsessa Hsiang Feiltä. Hagarin ja Tsh'ienniangin kokemus siis on kahdentumisessaankin sama.

Tsh'ienniang on pukenut kauneutensa ylleen kuin suojelevan naamion lähtiessään vastoin miehensä tahtoa tapaamaan mandariinia. Vang Tshou on raivostunut, koska taiteen ja julkisen elämän kunnianarvoisa kutsu on tullut vaimolle eikä hänelle. Myös naapurin vanha nainen väittää pilkallisena Tsh'ienniangin olevan lukutaidoton kuten muutkin naiset, ja tuohtuessaan tälle Tsh'ienniang osoittaa olevansa Hagar, kotoisin uudenlaisesta ajasta. Kohtaus kommentoi kirjailijuuden ja ajattelijuuden sukupuolta sekä naiselle avoimia rooleja. Uusi aika on tässä myös maailmansodan jälkeinen aika, naistaiteilijoille suopeampi kuin maailmansotaa edeltävä, josta Olsson kirjoitti Chitambossa (1933). Mutta konfliktilla on merkitystä myös rakenteellisena elementtinä. Kun Hagar Tsh'ienniangina lähtee mandariinin luokse, tarinaan aukeaa ylimäräinen lähtö. Se tuo Hagarin enemmän läsnäolevaksi Tsh'ienniangin hahmossa ja herättää tulkinnan mahdollisuuksien moneuden. Legenda ei ole enää aivan sama eikä allegoria suljettu.

Kirjaimellisin yhtymäkohta Tsh'ienniangin ja Hagarin tarinoissa on syyllisyys vanhempien jättämisestä. Tsh’ienniang lähti isänsä talosta Vang Tshoun takia, mutta minkä vuoksi Hagar lähti? Vai lähtikö hän? Ka’n luokse hän kenties lähti, nuoren sulhasen mukaan taas ei. Kabinetin ja liikkuvien maalausten kohtauksessa on selvää, että Hagar tuntee syyllisyyttä myös siitä, ettei lähtenyt rakastetun mukana toiseen makuntaan vaan kuvassa nähdyn tytön valinnalla kuihdutti mahdollisuutensa. Tsh'ienninangin legenda siis liitetään Hagarin tarinaan useilla eri tavoilla. Silkkimaalauksen kerronta on sillä tavoin tyyliteltyä, että rakkaustarinat ja rakkauden menetykset rinnastuvat toisiinsa; esimerkiksi kaukaa nähty ja hätkähtäen tunnistettu hahmo tai luonnon helmassa viipyvä rakastavainen pari esiintyvät monina variaatioina. Paitsi toisiinsa, ne rinnastuvat Tsh'ienniangin legendaan. Vang Tshoun vuoksi Tsh'ienniang "pakeni salaa isänsä kodista"; Hagarin nuoruudenkihlattu rukoilee tätä "jättämään isänsä talon”. (S 19, 44.) Vang Tshou tarttuu Tsh’ienniangin käteen "ja me leimahdimme molemmat"; Hagarin ja Ka’n istuessa Ka kohottaa kätensä ja "tuli kiiti lävitseni päästä jalkoihin”. (S 23, 33.)

Vang Tshou on siis nuoruuden kihlattu ja Ka. Alun monologissa on läsnä tuntematon joukko muitakin ihmisiä, jotka kutsuvat Hagaria: "Minusta erkanivat elävät virrat, jotka välkkyen etsivät tietään ihmismeressä, ja ilman kautta sain väriseviä 
viestejä sydämiltä, jotka olivat yhtä hehkuvia ja toivontäysiä kuin omanikin (S 8).” Sama vaikea valinta ja syyllisyys tunnustetaan suhteessa toisten ihmisten kollektiiviseen kutsuun. Mahdollisuudet on hukattu omasta suuresta syystä, ja Hagar näkeekin oikeutettua tuomitsevuutta näkyjensä hahmoissa: "Heidän ihanuutensa oli niin suuri, että halusin vaipua maan alle häpeäni tähden" (S 14), ”Ne asettuvat aivan kattokruunun alle, täyttymättömän elämänyhteyden aavemaiseen valoon, ja tuomitsevat sinut iankaikkiseen velkaan” (S 9). Legenda laajenee kuvittamaan rakkauden vastaanottamista tai hylkäämistä, haluun ja tahtoon liittyviä valintoja.

Legendassa on kaksi poissulkevaa impulssia, rakastetun seuraaminen ja kuuliaisuus vanhemmille. Ratkaisuna on saada molemmat, olla sekä omassa että vanhempien talossa. Ambivalenssi jää voimaan mutta on silti mahdotonta, sillä kotiin jäänyt Tsh'ienniang on unessa. Vielä yksi tapa tulkita legendaa onkin Hagarin syyllisyys siitä, että hän ei ole suostunut valitsemaan vaan on tahtonut kaiken. Tämä kohtuuton halu on merkinnyt puolittaista, vieraantunutta olemassaoloa, kiinnittymistä ei-mihinkään. Molempien valitseminen on sama kuin ei minkään valitseminen, samoin kuin ambivalenssi on aina sekä kahtalaisuutta että häilyvää ei-kumpaakaan. Tsh'ienniangin legenda on siis ambivalenssin liioittelua ja kirjaimellisuutta, johon sisältyy yliluonnollinen mahdottomuuden elementti. Hagarin elämässä tämä merkitsee sitä, että kaikille kutsuille on sanottu yhtäläisesti ei, ja Hagar on tajuttomassa unessa, hänellä on ”ontelo rinnassa" tai hänen "elämänsä on pysähtynyt hänen vielä eläessään" (S 33, 7).

Vanhempien tahto ja oma tahto, rakkaus ja kutsumus, avioliiton tuoma asema ja sen torjuminen, toisiin ihmisiin liittyvä ja itseensä vetäytyvä elämä - nämä kaikki ovat mahdollisia sisältöjä legendan ristiriidalle. Legenda kertoo yhteen kaksi valintaa, kaksi syyllisyyttä ja monta eri henkilöasetelmaa. Tsh'ienniangin tarun sovinto ei siis paranna vain yhtä repeämää, vaan täydellisen rauhan fantasiassa ne kaikki. Ja koska legenda Hagarin elämänä kertoo vuorollaan sekä naisen että miehen rakkauden valitsemisesta, sen ristiriita ei palaudu homo- ja heteroseksuaalisen rakkauden poissulkevuuteen. Legendan osuus kertomuksessa ei tunnusta tätä poissulkevuutta, vaikka kertomus muuten kuvaakin sukupuolieroja yhteisöllisine ulottuvuuksineen: Hagarin ja kihlatun tarina asettuu legendan kautta analogiseksi Hagarin ja Ka’n tarinalle, ei sen vaihtoehdoksi. Lisäksi kertomus vastustaa näin kertakaikkista valheen ja totuuden, väärän ja oikean itsen välistä jakoa, joka olisi rikkumaton kaapin epistemologian toteutuma. Ajan ja tilan vuorovaikutus on tässäkin merkittävää: legendan variaatioihin liittyvä kerronnallisen ajan monimutkaisuus luo tilan sen mahdollisimman ambivalentille tulkinnalle.

\section{"Vieraat viipyvät auringonnousuun asti"}

Koko kertomuksensa ajan, paitsi milloin pääsee pakenemaan näkyihin, Hagar on toisista ihmisistä erotettu. Mandariinin palatsissa hän näkee kauniita tuntemattomia 
ja myös tuttuja, etenkin Ka’n, mutta nämä eivät näe häntä vaan vaikuttavat välinpitämättömiltä ja tuomitsevilta. Hagaria ajaa eteenpäin puutarhassa kuultu salaperäinen säe "vieraat viipyvät auringonnousuun asti", yhteisyyden lupaus. Kun Hagar löytää paviljongin, hän pääsee sinne "viimeinkin". Ensin vain on pitänyt eksyä ja antautua johdatettavaksi. Juhlaan pääseminen ei lopulta hämmästytä Hagaria lainkaan: ”Tuntui aivan siltä kuin olisimme eronneet vain hetki sitten, kuin olisimme nukahtaneet tuokioksi juhlan jatkuessa ja viinin vähetessä ruukuissa - -” (S 49). Tsh'ienniangin legendasta on koettu lähtö muttei vielä paluuta. Sovinto on luvattu ja se saadaan enteiden mukaisesti juhlissa, jotka jatkuvat auringonnousuun.

Eksyminen ja enteet ovat merkityksellisiä narratiivisuuden ja tiedon yhteenkietoutuvuudelle. Eksynyt kadottaa tien mutta löytää sen uudelleen, enne on tieto, joka on olemassa, mutta ensin piilotettuna. Lopputuloksena on tieto, ja eksyminen on ollut tarvittava kiertotie, jotta alkuperäiseen (ja siis väistämättömään) voitaisiin palata - kuten narratiivinen norminmukaisuus edellyttää. (Roof 1996, 75, 86.) Eksyminen kuvana kaikuu myös käsitystä (seksualisoidusta) itsestä paljastettavana totuutena. Silkkimaalaus käy todellakin lähellä fantasiaa täydellisestä tiedosta ja rauhasta. Juhla mandariinin paviljongissa rakentuu viimeiseksi ja täydellisimmäksi tilaksi, johon kootaan kaikki tärkeät henkilöt samassa ajassa sijaitsevina. Mandariini on "parhaalla kertojantuulellaan" - hänet yhdistetään isään, jota kuvailtiin aiemmassa lapsuusnäyssä samoin sanoin. Mandariinin vaimo on äiti, joka lohduttavasti toteaa "löysimme lopulta toisemme”. Ka on läsnä, samoin joukko ystäviä, joilla on kotoisat ominaisuutensa ja nimetkin, kuten Toya ja Artur. Kohtauksessa myös nauretaan helpottuneesti lemmikkiapinalle, joka luulee jonkin asian maailmassa vielä olevan hätänä. Hagar ja Ka saavat kahdenkeskisen hetken, ja kaikki suhtautuvat arvostavasti heidän yhteyteensä. (S 47-51.) Erilaiset suhteet saavat olla olemassa ja valintojen karvaus on haihtunut. Oikeastaan kuva sovinnosta on eksessiivinen, niin että se menettää uskottavuuttaan ja on kumoutua.

Lopussa kuitenkin tapahtuu jotakin, mikä tempaisee kerronnan irti, nimittäin "ihme". Vaikka Hagarin matka on tapahtunut niin kuin oli määrä, mikään kertomuksessa ei varsinaisesti valmista aamuruskosta ratsastavaan, "ihmisen voitonlaulua" laulavaan mieheen. Kuva on orgastinen ja peittää näkyvistä kaiken muun: "irtaannuin kaikesta mikä oli omaani ja minkä olin jättänyt taakseni, en nähnyt muuta kuin auringon nousun. [- - Temppeliportista liekehtivien vuorten keskeltä tuli ratsastaen yksinäinen mies, hänen kasvonsa olivat kauniimmat kuin kieli voi kertoa, ja sydämessään hän kantoi ihmislasten kyyneliä.” (S 52).

Ilman yhteyttä Olssonin 40-luvun lopun ajatteluun kristuksenkaltainen hahmo on vaikeasti ymmärrettävissä. Mies edustaa "universaalia minää", ajatusta, jota Olsson kehitteli Jag lever-esseessä. Ihminen on joutunut oman älyllisyytensä ohittamaksi niin, 
ettei henkinen kehitys ole voinut seurata tekniikan saavutuksia. Rationaalisuus on pettänyt ihmisen, joten parannusta pitäisi etsiä mystisestä, hengellisestä ja intuitiivisesti ymmärrettävästä. Tätä Olssonille edustavat Aleksis Kiven viimeiset sanat, joissa puhuu yksilöstä riippumaton minä. Minä elän -lauseessa toteutuu eräänlainen ylösnousemus, persoonallisuuden ylittäminen. Olssonin ajatukset vieraantumisesta näkyvät Silkkimaalauksen alkumonologin todistuksessa siitä, miten ihminen voi joutua syrjään elämästään vielä eläessään. Kahdentuminen, itsensä viereen joutuminen, on myös sama ajan sairaus, jota Jag lever on kirjoitettu lääkitsemään.

Mielenrauha ei olekaan riippuvainen vain itsetuntemuksesta, vaan Olsson sitoo sen yksilöllisyyden ylittävän ihmisyyden mysteeriin. Yksilöllisyyden valintoineen ja syyllisyyksineen on annettava raueta. Tsh'ienniangin kahdentuminen ja ehjäksi tuleminen on kuva myös tälle itsestään kauaksi joutuneen ihmisen valaistumiselle. Voisi kysyä, viimeisteleekö auringonnousun kliimaksi totuuden etsinnän tavalla, josta Judith Roof puhuu (re)produktiivisuutena ja joka kannattelee narratiivin ideologisuutta (Roof 1996, 13-17), vai onko hyppäys mystiseen ja universaaliin niin suuri, että se irtoaa tästä normatiivisuudesta. Kysymys siis kuuluu, mitä ambivalenssille tapahtuu tässä ilmestyksessä.

Viimeisellä sivulla, joka sijoittuu jälleen Hagarin huoneeseen, on läsnä kolme kerrottua tarinaa edustavaa elementtiä: maalaus, laulu ja runo. Ensimmäinen on silkkimaalaus, Ka’n lahja, jonka antoi "rakastettu käsi aamukoitteessa". Lukuisien ekfrasisten vuoksi on helppo ajatella, että matka on alun perinkin tehty juuri tässä maalauksessa. Maalaus on silmukka ajassa: loppu läsnä alussa ja alku lopussa, muodon suljettuus. Toisaalta sen olemus on pako: houkutus astua tauluun pois todellisuudesta "kuten maalari Vu”, joka katosi maalauksensa luolaan. Tältä houkutukselta varjelee auringonlaskusta ratsastaneen miehen voitonlaulu. Kun yksilön kaikki toiveet ovat toteutuneet aamun jatkuneissa juhlissa, nousee aurinko ja muistuttaa yksilöä suuremmasta, joka voittaa ja sisältää kaiken. Maalauksen taika raukeaa, sen ”saavat kaikki nähdä”. Mutta on jotain muuta mitä kaikki eivät saa nähdä, nimittäin "pieni kiinalainen runo". ”Sen sisältöä en ilmaise kenellekään”, kuuluvat teoksen viimeiset sanat. (S 53.) Tämä voisi olla palatsissa kuultu runo, josta jää kaikumaan kutsuva viimeinen säe, tai toisaalta Toya-ystävän juhlissa kirjoittama. Toya kirjoittaa runonsa Ka’n lahjan inspiroimana ja se on sikäli tulkinta Ka’n ja Hagarin rakkaudesta. Kukaan ei tiedä, mikä tämä merkityksellinen tulkinta on, eikä lukijakaan täysin tiedä, mikä tuo mysteeriksi jätettävä runo on. Se edustaa siis salaisuutta, joka jättää kerronnan sulkematta.

Silkkimaalaus piirtää elämästä kuvan, jossa rakkaudesta on kerrottu mutta joka ei muodostu ensisijaiseksi kuvaksi heteroseksuaalisuudesta, homoseksuaalisuudesta tai myöskään biseksuaalisuudesta. Totuus itsestä ei typisty seksuaalisuuteen tavalla, joka kannattelisi normatiivista narratiivin, tiedon ja seksuaalisuuden yhteenkuuluvuutta. 
Silkkimaalaus kuvaa itsen etsimisen, mutta ei kehkeytymistä kohti identiteettikategoriaa. Tunnustuksellisena se viittaa "todelliseen elettyyn elämään”, joka on loputtoman moninainen. Fiktiona se kuitenkin ylittää omaelämäkerrallisuutensa. Silkkimaalauksen hienovireinen ei-typistyneisyys on kirjallisten keinojen vaikutusta, sitä, mikä kerronnassa voi vastustella kerronnan logiikkaa.

Vaikka Tsh'ienniangin legenda antaa vihjeen kaksijakoisuuden ja yhdistymisen temaattisesta keskeisyydestä, ei vihjettä ole yksinkertaista seurata. Legendalla on teoksessa niin monia funktioita, ettei sille ole mielekästä etsiä suoraa käännöstä. Se muodostuu kuvaksi ambivalenssista itsestään. Samalla se yhdistää toisiinsa kahtiajakautumisen teemat, joita on useita. Hagar Olssonin ihmisyyttä koskevaa ajattelua vasten Silkkimaalaus kertoo ambivalenssista kahdella tavalla: itsestään erkautunut minä kokee ambivalenssin lamaannuttavina ristiriitoina. Toisaalta estetiikan ja etiikan, kauneuden ja totuuden toiveikas läsnäolo on sekin ambivalenssia, joka pakenee koko (läntisessä) maailmassa painostavaksi käynyttä rationaalisuutta. Pakeneminen ei näyttäydy torjuvana ja ulossulkevana vaan sovintoa etsivänä ja sisällyttävänä. Samalla Silkkimaalaus saa kysymään, mitä muuta kuin aggressiivisen kiistävää vallitsevan ihmiskuvan haastaminen voi olla ja tarvitseeko ambivalenssin ilmaiseminen juuri pehmeyttä ja runollista sumeutta, "arvoituksellista suloa".

\section{Viitteet}

${ }^{1}$ Nämä väitteet tiedosta ja seksuaalisuudesta liittyvät niin sanottuun kaapin epistemologiaan. Eve Kosofsky Sedgwickin (1990) muotoilema queer-teorian peruskäsite ilmaisee havainnollisesti, miten hetero- ja homoseksuaalisuuden välinen kahtiajako jäsentää modernia länsimaista merkitysjärjestelmää. Tämä vastakohta sävyttää loputtomia vastakohtapareja ja vastakohtaisuutta itseään, sekä ennen kaikkea ilmaistun ja ei-ilmaistun, tiedetyn ja ei-tiedetyn vastakohtaa (mt. 2-3, 10-11). Kaappi on erityisen ei-tietämisen tila, latautunut ja merkityksiä tuottava. Kaapin ja ulkopuolen rajan ylittäminen on rituaalinen, painava teko, jota säätelee kulttuurinen ymmärrettävyys.

${ }^{2}$ Elämäkerturi Roger Holmström puhuu Olssonin rakkaus- ja ystävyyssuhteista osana elämäkertaa. Hän nimeää kertaalleen suoraan "rakkauden naisen ja naisen välillä", mistä vähintään käy selväksi, että naisten väliset suhteet on luettava merkityksellisiksi (Holmström 1993, 147). Toki esimerkiksi Olssonin lyhyehköstä suhteesta Wäinö Aaltoseen annetaan eksplisiittisempää tietoa rakkaussuhteena, muun muassa sisällyttämällä kuvaliitteeseen Aaltosen piirtämä eroottinen kuvatervehdys. Naissuhteiden kuvauksessa korostuu intohimoinen ystävyys, luottamus ja usein myös tuki ja turva. Symmetriaa kuvauksessa ei siis ole, mutta avoimuutta kyllä. Mari Koli pitää Holmströmin hienovaraisuutta arveluttavana ja turhan heteroseksuaalista kuvaa Olssonista piirtävänä (Koli 1996).

${ }^{3}$ Ellen Rees lukee Chitamboa (1933) teoksena, jonka kaksitasoinen kerronta konkretisoi kutsumuksen ja rakkauden, maskuliinisen ja feminiinisen kohtalon ristiriidan. Sille etsitään analogioita Olssonin elämästä ja tuotannosta, mies- ja naissuhteiden väliltä, modernistin ja 
modernismin kriitikon roolien väliltä. (Rees 1999.) Silkkimaalausta ja Chitamboa yhdistävät ristiriidan ja valinnan sekä vanhempi-lapsi-suhteen teemat.

${ }^{4}$ Synekdokee ja metonymia tulevat tässä käytetyiksi yksittäistä kielikuvaa laajempina käsitteinä, samoin kuin metaforakin Brooksin tapaan alun ja lopun suhteen kuvauksena. $\mathrm{Ne}$ kuvaavat siis millaisten suhteiden varassa kerronta etenee. Klassiset kerronnan teoriat kuvaavat kerronnallista jännitettä vuorovaikutuksena, jossa metonymia viivyttää ja assosiaatioin eksyttää metaforan puoleensavetävää voimaa. (Brooks 1984, 24-29.) Silkkimaalauksessa erityistä on metonymian ja synekdokeen visuaalinen ja tilallinen korostuneisuus, niiden kirjaimellisuus.

${ }^{5}$ Käytän normatiivisuus-sanaa siksi, että se viittaa oikean ja kannustetun lisäksi myös tavalliseen ja odotuksenmukaiseen. Normatiivisuus on sitä säätelevää vaikutusta, joka huomaamatta toteutuu tunnistettavissa merkityksissä ja totutuissa käytännöissä sekä niitä häiritsevän välttämisessä.

\section{Kaunokirjallisuus}

OLSSON, HAGAR I 949: Kinesisk utflykt. Helsingfors: Holger Schildts Förlag. S = OLSSON, HAGAR I954: Silkkimaalaus. Suom. Eeva-Liisa Manner. Helsinki: WSOY.

\section{Tutkimuskirjallisuus}

BRoOKs, PETER I984: Reading for the Plot. Design and Intention in Narrative. Cambridge \& London: Harvard University Press.

FRANK, JOSEPH I 963: Spatial Form in Modern Literature. Teoksessa The Widening Gyre: Crisis and Mastery in Modern Literature. New Brunswick: Rutgers University Press, s. $3-62$.

GARBER, MARJORIE 2000: Bisexuality \& The Eroticism of Everyday Life. New York: Routledge.

HAASJOKI, PAULIINA 2005: Mitä tiedät kertomuksestani. Biseksuaalinen ambivalenssi ja queer-lukeminen. Naistutkimus - Kvinnoforskning 2/2005, s. 29-39.

HAASJOKI, PAULIINA 2007: Varmuuden vuoksi ei. Ruoka, halu ja ambivalenssi Eva Weinin teoksissa. Teoksessa Siru Kainulainen ja Viola Capkova (toim.), Täysi kattaus. Ruokaa ja juomaa kirjallisuudessa. Turku: Turun yliopisto. s. 159-190.

HOLMSTRÖM, ROGER I993: Hagar Olsson och den öppna horisonten: liv och diktning 1920-1945. Helsingfors: Schildts.

HOLMSTRÖM, ROGER I995: Hagar Olsson och den växande melankolin: liv och diktning 1945-1978. Helsingfors: Schildts.

нӧккё, тUULA I 999: Modernismi: uusi alku - vanhan valtaus. Teoksessa Pertti Lassila (toim.), Suomen kirjallisuushistoria 3. Helsinki: SKS.

JAGOSE, ANNAMARIE 2002: Inconsequence. Lesbian Representation and the Logics of Sexual Sequence. Ithaca \& Lontoo: Cornell University Press.

KARKulehto, sanna 2007: Kaapista kaanoniin ja takaisin. Johanna Sinisalon, Pirkko 
Saision ja Helena Sinervon teosten queer-poliittisia luentoja. Oulu: Oulun yliopisto. KARTTUNEN, PÄIVI I989: "Ehkä seuraava naissukupolvi" - Hagar Olsson. Teoksessa Marja-Liisa Nevala (toim.), "Sain roolin johon en mahdu". Suomalaisen naiskirjallisuuden linjoja. Helsinki: Otava.

KEKKI, LASSE 2004: Pervot pidot. Johdanto homo-, lesbo- ja queer-kirjallisuudentutkimukseen. Teoksessa Lasse Kekki ja Kaisa Ilmonen (toim.), Pervot pidot. Homo-, lesbo-ja queer-näkökulmia kirjallisuudentutkimukseen. Helsinki: Like.

KOLI, MARI I996: Hagar Olsson: den finländska litteraturens Greta Garbo-gestalt? Nya Argus 1996: 19.

mezei, кathy (толм.) I996: Ambiguous Discourse. Feminist Narratology and British Woman Writers. Chapel Hill \& London: University of North Carolina Press.

OLSSON, HAGAR 1987/1948: Jag lever. Stockholm: Janus Förlag.

OLSSON, HAGAR I993 (I933): Chitambo. Helsinki: Schilds.

REES, ELlen 1999: Hagar Olsson's Chitambo and the Ambiguities of Female Modernism. Scandinavian Studies summer 1999, vol. 71, nr 2, s. 191-206.

ROJOLA, LEA I995: Varmuuden vuoksi. Modernin representaatio Volter Kilven saaristosarjassa. Helsinki: SKS.

ROOF, JUdith I996: Come as you are. Sexuality and Narrative. New York: Columbia University Press.

rosenberg, tiIna 2004: Tintomara. Queerteatraalinen luenta C.J.L. Almqvistin romaanista Kuningattaren jalokivikoru. Teoksessa Lasse Kekki ja Kaisa Ilmonen (toim.): Pervot pidot. Homo-, lesbo- ja queer-näkökulmia kirjallisuudentutkimukseen. Like, Helsinki.

ROSSI, LEENA-MAIJA 2003: Heterotehdas. Televisiomainonta sukupuolituotantona. Gaudeamus, Helsinki.

SEDGWICK, EVE KOSOFSKY I990: Epistemology of the Closet. Los Angeles: University of California Press.

SMitTen, JefFrey R. JA ANN DAghistany (RED.): Spatial Form in Narrative. Ithaca \& London: Cornell University Press.

waugh, patricia i984: Metafiction: The Theory \& Practice of Self-Conscious Fiction. Florence: Routledge. 